\title{
Seasonal patterns of viral, microbial and planktonic communities in Sidi Salem: a freshwater reservoir (North of Tunisia)
}

\author{
Samira Ben Romdhane ${ }^{1 *}$, Monia El Bour ${ }^{1}$, Asma Hamza $^{1}$, Fourat Akrout ${ }^{1}$, \\ Mohamed Mejdeddine Kraiem ${ }^{1}$ and Stéphan Jacquet ${ }^{2}$ \\ 1 Institut National des Sciences et Technologies de la Mer (INSTM), 28 rue du 2 mars 1934 -Salammbô, Tunisie \\ 2 INRA UMR 42, Centre Alpin de Recherches sur les Réseaux Trophiques des Ecosystèmes Limniques, 74203 Thonon Cedex, France
}

Received 20 February 2014; Accepted 10 September 2014

\begin{abstract}
We investigated the distribution and dynamics of viruses, prokaryotes and small eukaryotic phytoplankton in Sidi Salem freshwater reservoir (Northern Tunisia). Samples were collected from the deepest station at different depths throughout the water column for 2 years (February 2009 to January 2011). The reservoir was characterized by seasonal alternations of thermal stratification and homothermy. Among the different microbial communities counted using flow cytometry (FCM), picocyanobacteria constituted an important autotrophic component since they were always present and their highest concentration reached 3.02 and $2.65 \times 10^{5}$ cells. $\mathrm{mL}^{-1}$ in March 2009 and June 2010, respectively. The heterotrophic prokaryotic communities (represented mainly by bacteria) were characterized by a clear separation between two subgroups referred to as high-DNA and low-DNA content populations, and the highest concentrations of heterotrophic bacteria (i.e., $3.8 \times 10^{7}$ cells. $\mathrm{mL}^{-1}$ ) were recorded in spring 2009 . Several viral groups referred to as virus-like particles (VLP) groups 1, 2 and 3 could also be discriminated using FCM. VLP1 and VLP2 displayed a significant correlation with the heterotrophic bacteria $(r=0.80$ and $0.78, P<0.001)$ but seem to be independent from picocyanobacteria and/or chlorophyll $a$, suggesting these VLPs were mainly bacteriophages. At last, the virus to prokaryotic ratio could be high, especially in summer (mean $=22$, $\max =487$ ), suggesting a strong coupling between bacteria and viruses, at least at certain periods of the year.
\end{abstract}

Key words: Flow cytometry / viruses / bacteria / picocyanobacteria / freshwater reservoir

\section{Introduction}

In aquatic microbial ecology, the term picoplankton traditionally refers to all cells that fall into the size class $0.2-3 \mu \mathrm{m}$; that includes picocyanobacteria, heterotrophic bacteria, archaea and small eukaryotic phototrophs referred to as picoeukaryotes (Li et al., 1983; Whitman et al., 1998; Worden and Not, 2008; Auguet et al., 2010). These heterotrophs contribute largely to the cycling of carbon and nutrients in aquatic systems (Sarmiento and Gruber, 2006) and also form an important nutrient resource for higher trophic levels (i.e., the heterotrophic nanoflagellates, ciliates, metazooplankton) (Parvathi et al., 2014).

Autochthonous and allochthonous factors can impact both auto- and heterotrophic organisms, affecting their distribution, structure, diversity as well as interactions among the organisms. The dynamics of picoplankton in aquatic ecosystems are not only controlled by abiotic

*Corresponding author: samirabenromdhane@yahoo.fr factors (temperature, light and nutrients), but also by biotic factors such as natural death, viral lysis, predation and parasitism (Parvathi et al., 2014). Viruses play an important role in regulating carbon and nutrient fluxes, food-web dynamics and microbial diversity in aquatic systems (Suttle, 2005; Jacquet et al., 2010; Breitbart, 2012). The factors that influence viral abundance and dynamics in aquatic environments are complex and are found to vary with aquatic ecosystems (Clasen et al., 2008). Studies have shown that the viral abundance is influenced more by the bacterial abundance in marine environments and by chlorophyll $a$ concentration in nutrient-rich lakes (Pradeep Ram et al., 2010). A few studies in the lacustrine environments have included the influence of grazers on the picoplankton and bacterial abundances in studying viral dynamics (Personnic et al., 2009; Berdjeb et al., 2011).

The expansion of urban areas associated with agricultural pressure has promoted the progressive eutrophication of surface waters worldwide, contributing to the deterioration of water quality (Ben Rejab Jenhani 
et al., 2012). Such hydrosystem dystrophy leads generally, because of excessive nutrient enrichment, to symptomatic changes such as increasing production of aquatic macrophytes, the apparition of phytoplankton blooms (among which harmful cyanobacteria), the loss of biodiversity, the modification of transparency and of water coloration (Dauta and Feuillade, 1995).

Tunisia is a Mediterranean country characterized by aridity on the major part of its territory. To this aridity is added the variability of the Mediterranean climate, with erratic and unpredictable periods of large drought and violent floods, so that water is often limited and distributed unequally in time and space (Benzarti, 2003). Facing this shortage of water, Tunisia has developed a strategy of surface water resources mobilization. Consequently, the continuous increase of artificial water systems (reservoirs) has provided a privileged investigation field for limnological research (Ben Mammou and Louati, 2007). Being the first link in the food webs, phytoplankton plays a crucial role in aquatic ecosystems. All processes related to this compartment may affect directly or indirectly the environment. Thus, a monitoring of the environmental conditions and phytoplankton assemblages has been carried out in several reservoirs from which problems of eutrophication, especially due to phosphorus, have often lead to significant shifts in phytoplankton species' composition towards bloom-forming cyanobacteria and could result in fish mortality (Mouelhi et al., 2000; Turki, 2002; Ben Rejab Jenhani et al., 2006; Fathalli et al., 2006; El Herry et al., 2008). The Sidi Salem reservoir, investigated in the context of this study, is intensively used for irrigation and provides drinking water, fish breeding and electric power supply in the Northwest of Tunisia. It is thus a reservoir of major importance for multiple purposes and its environmental survey is critical.

So far, only a few studies have been conducted in such a reservoir dealing with plankton dynamics and nothing is known about some key microorganisms such as the pico- or the virioplankton. Indeed, researches carried out so far on this temperate reservoir have been limited and mainly concerned sedimentology, fish farming and zooplankton diversity (Ben Mammou, 1998; Mouelhi et al., 2000; Djemali et al., 2003). To the best of our knowledge, this is thus the first study of different viral and microbial communities for this reservoir that was sampled for such a goal during two consecutive years. Furthermore, it is appearing that study can currently evaluated the vertical distribution of micro-organisms in the deepest zone of the reservoir and to assess the relationships between these communities and their chemical and/or physical environment in the semi arid region.

\section{Materials and methods}

\section{Sampling site}

The Sidi Salem dam $\left(36^{\circ} 35^{\prime} 20^{\prime \prime} \mathrm{N}\right.$ and $\left.9^{\circ} 23^{\prime} 45^{\prime \prime} \mathrm{E}\right)$ is located at $8 \mathrm{~km}$ in the North Western part of the town of
Table 1. Morphometric and hydrologic characteristics of the studied reservoir (Meteorology Service and Agricultural Minister of Tunisia, 2011).

\begin{tabular}{ll}
\hline & Sidi Salem Reservoir \\
\hline Latitude & $9^{\circ} 23^{\prime} 34^{\prime \prime} \mathrm{N}$ \\
Longitude & $36^{\circ} 35^{\prime} 40^{\prime \prime} \mathrm{E}$ \\
Construction & 1981 \\
Water stream & Medjerda stream \\
Surface area (ha) & 4710 \\
Maximum depth (m) & 57 \\
Volume $\left(\mathrm{mm}^{3}\right)$ & 485 \\
Water temperature $\left({ }^{\circ} \mathrm{C}\right)$ & 18 \\
Annual mean precipitation $(\mathrm{mm})$ & 450 \\
Annual mean inputs $\left(\mathrm{mm}^{3}\right)$ & 334.3 \\
Annual mean evaporation $(\mathrm{mm})$ & 1493.5 \\
Annual mean siltation $\left(\mathrm{mm}^{3}\right)$ & 6.8 \\
\hline
\end{tabular}

Testour. It has been built on the Medjerda stream in 1981 . It is considered as one of the largest dams in Tunisia with a $4300 \mathrm{~km}^{2}$ area, and $57 \mathrm{~m}$ of maximum depth (Table 1). This dam is used for irrigation; drinkable water, fish farming and electric power supply (Fig. 1). For our purpose, water samples were collected monthly from February 2009 to January 2011, using a 1-L containing Niskin bottle at different depths $(0,5,10,15,20$ and $25 \mathrm{~m})$ from the deepest station in the reservoir.

\section{Environmental parameters}

Water temperature, salinity, $\mathrm{pH}$ and dissolved oxygen concentrations were measured using a multi-parameter probe (WTW model). Transparency was measured using the Secchi disc. Dissolved inorganic nutrient $\left(\mathrm{NO}_{3}^{-}-\mathrm{N}\right.$, $\left.\mathrm{NO}_{2}^{-}-\mathrm{N}, \mathrm{PO}_{4}^{3-}-\mathrm{P}, \mathrm{NH}_{4}^{+}-\mathrm{N}, \mathrm{Si}(\mathrm{OH})_{4}\right)$ were measured using colorimetric methods with the autoanalyseur Bran-Luebbe III. The chlorophyll a concentration was determined from $300 \mathrm{~mL}$ of water filtered on Whatman GF/C filters ( $0.45 \mu \mathrm{m}$ pore size filter and $25 \mathrm{~mm}$-diameter), and the quantity of pigments was determined using a fluorometric method (Welschmeyer, 1994) after a methanol extraction (Herbland et al., 1985).

\section{Biological parameters}

Roughly $2 \mathrm{~mL}$ samples were fixed with paraformaldehyde ( $2 \%$ final concentration) for $30 \mathrm{~min}$ in the dark, flash frozen in liquid nitrogen and kept at $-80^{\circ} \mathrm{C}$. Autotrophic small eukaryotes, picocyanobacteria, heterotrophic bacteria and viruses were counted using a FACSCalibur flow cytometer (Becton Dickinson) equipped with an air cooled laser providing $15 \mathrm{~mW}$ at $488 \mathrm{~nm}$. Before flow cytometry (FCM) analysis, samples were thawed at $37^{\circ} \mathrm{C}$ and preceded immediately. For bacterial and VLP analysis, $5 \mu \mathrm{L}$ of the sample was diluted in $495 \mu \mathrm{L}$ of $0.02 \mu \mathrm{m}$ filtered TE buffer (0.1 mM Tris-HCL and $1 \mathrm{mM}$ EDTA, $\mathrm{pH} 8)$, and incubated with SYBR Green I (at a final $10^{-5}$ dilution of the commercial stock solution; Molecular Probes), for 

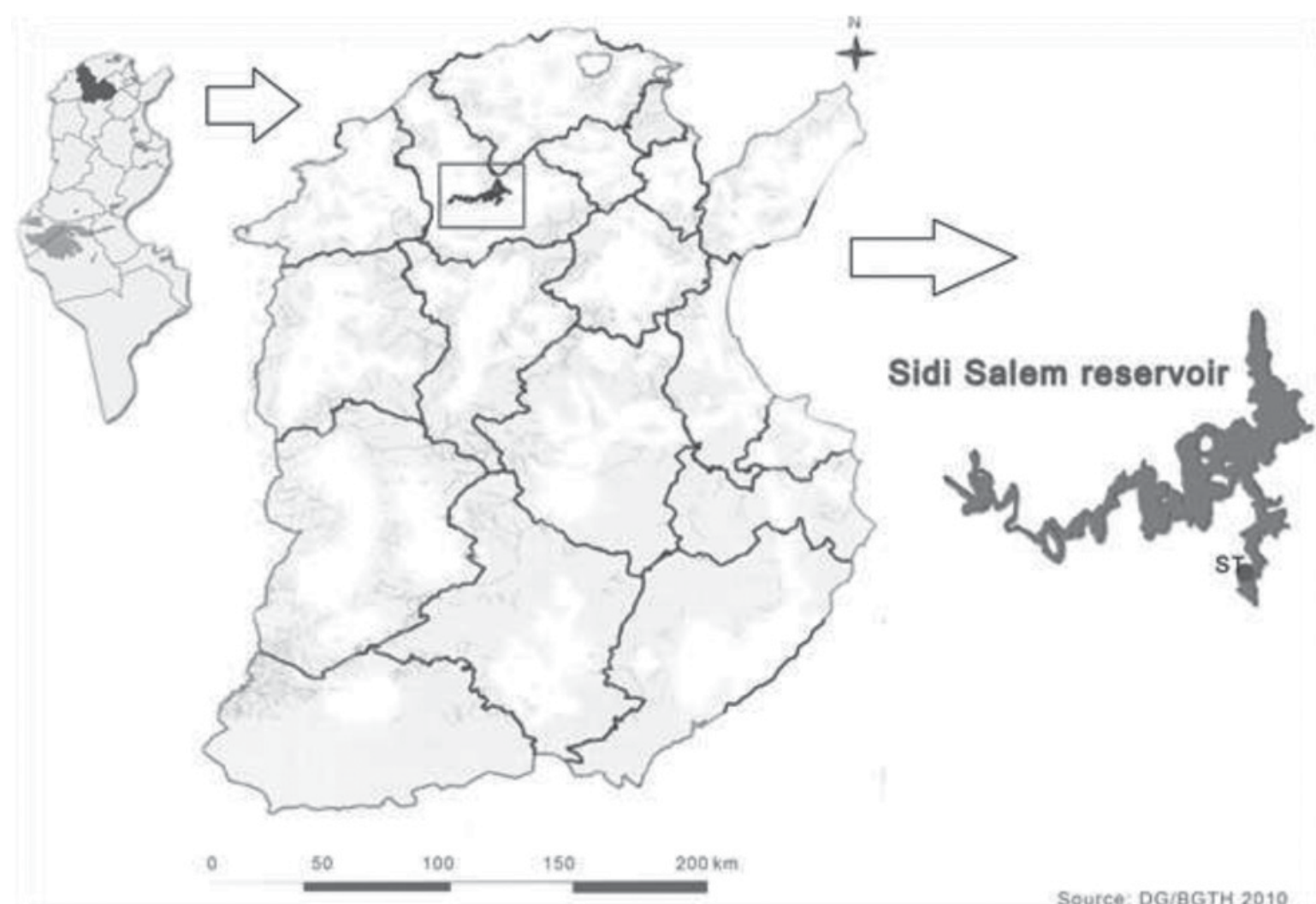

Source: DG/BGTH 2010

Fig. 1. Geographic location of the of Sidi Salem reservoir. ST• symbolizes the sampling station that corresponds to the deepest part of the reservoir.

5 min at ambient temperature, followed by $10 \mathrm{~min}$ at $75^{\circ} \mathrm{C}$, and $5 \mathrm{~min}$ after at room temperature, prior to $\mathrm{FCM}$ analysis (based on Brussaard (2004) and modified by Jacquet et al., 2013). For photosynthetic cells (i.e., the picocyanobacteria and small eukaryotes) no fluorochrome was added. Thus analysis was made on 1-mL fixed samples in which a suspension of $1-\mu \mathrm{m}$ beads (molecular probes) previously diluted to be added. Two settings were used to analyse the autotrophic cells in order to discriminate all populations. Flow cytometer listmode files obtained were then transferred and analyzed on a PC using the customdesigned software CYTOWIN (Vaulot, 1989). More details about the FCM analysis and data treatment can be obtained elsewhere (Marie et al., 1999, 2000).

\section{Statistical analysis}

The data recorded in this study were submitted to a normalized principal component analysis (PCA) (Dolédec and Chessel, 1989). A Pearson test performed with XLstat was used to determine the correlations between the selected microorganisms groups and environmental variables. The data recorded for the viral, microbial and planktonic (Picocyanobacteria) communities' composition between depth and seasons were submitted to analysis of variance (ANOVA). Data were transformed in $\ln (x+1)$ where necessary to meet the assumption of homogeneity of variances (homogeneity confirmed by non-significant
Cochran's $C$-test). Studente-Newmane-Keuls (SNK) test was employed for a posteriori multiple comparisons of means between the season and depth.

\section{Results}

\section{Hydrological characteristics}

Water temperature was on average $18 \pm 7.1^{\circ} \mathrm{C}$, with the highest temperatures $\left(28\right.$ and $\left.26.9^{\circ} \mathrm{C}\right)$ recorded in summer (2009 and 2010) (Table 2). A thermal stratification developed during spring and summer. The spring brewing was mainly observed in May (2009 and 2010) between 10 and $15 \mathrm{~m}$. A well-marked thermocline was observed between 10 and $15 \mathrm{~m}$, in July 2009, while it started at $5 \mathrm{~m}$ depth in August 2010. Water temperature began to mix at the end of autumn and was mixed throughout the water column during winter months (Fig. 2(A)). The mean concentration of dissolved oxygen varied between 5.7 and $8.6 \mathrm{mg} . \mathrm{L}^{-1}$, The highest values were recorded in the $0-10 \mathrm{~m}$ surface layer, and values decreased only slightly from summer to fall. No marked desoxygenation along the water column was recorded (Fig. 2(B)). The mean levels of salinity were between 0.8 and 1.2 g. $\mathrm{L}^{-1}$, the highest level $\left(1.1\right.$ and 1.3 g. $\left.{ }^{-1}\right)$ being observed in surface in summer and autumn 2010, with water level reduction and intense of evaporation (Fig. 2(C)). By contrast, the lowest values $\left(0.9\right.$ g. $\left.\mathrm{L}^{-1}\right)$ were 


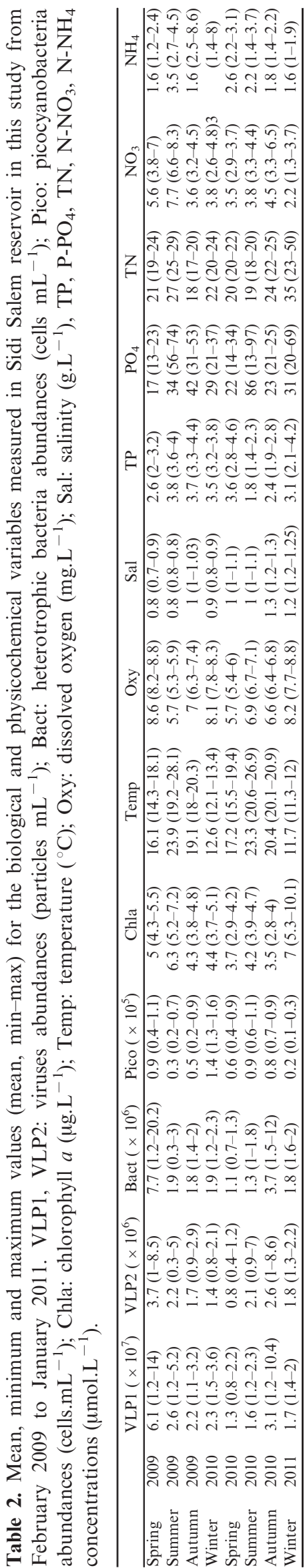

recorded in April 2009, coinciding with a previous rainy period. Transparency oscillated in a small range, between 0.75 and $3 \mathrm{~m}$, the lowest value being recorded in spring and the largest in winter. During the study period, $\mathrm{NO}_{3}^{-}$and $\mathrm{TN}$ displayed high concentrations with $3.74 \times 10^{1}$ and $5.06 \times 10^{1} \mu \mathrm{mol} . \mathrm{L}^{-1}$, respectively in January 2011, with two peaks marked at 10 and $20 \mathrm{~m}$. Along the water column, low nutrient concentrations were recorded in the epilimnion during spring and summer 2010 (Fig. 2(D) and (H)). $\mathrm{PO}_{4}^{3-}$ higher concentrations $\left(5.65 \times 10^{1}\right.$ and $\left.6.95 \times 10^{1} \mu \mathrm{mol} . \mathrm{L}^{-1}\right)$ were observed at $10 \mathrm{~m}$ in spring 2009 and deeper in January 2011, while low concentrations $\left(1.32 \times 10^{1} \mu \mathrm{mol} . \mathrm{L}^{-1}\right)$ were recorded during summer 2010 (Fig. 2(E)). $\mathrm{NH}_{4}^{+}$oscillated between 0.8 and $8.03 \mu \mathrm{mol} . \mathrm{L}^{-1}$ (Fig. 2(H)). N/P was relatively high (14.63) in January 2011, along the water column and showed fluctuations closely related to the seasonal cycle, in association with rainy periods or biological assimilation. $\mathrm{Si}(\mathrm{OH})_{4}$ ranged from 1.08 to $9.27 \times 10^{1} \mu \mathrm{mol}^{-\mathrm{L}^{-1}}$ along the water column, increasing gradually with depth. $\mathrm{Si}(\mathrm{OH})_{4}$ patterns followed the seasonal water stratification, but a decrease occurred throughout the stratification processes. Chlorophyll $a$ displayed almost identical temporal succession in the water column, with a high level (7.75 mg. $\mathrm{m}^{-3}$ ) marked in January 2011 in the different layers. The minima levels were registered during the autumn with the lowest concentration $\left(2.80 \mathrm{mg} \cdot \mathrm{m}^{-3}\right)$ marked in $25 \mathrm{~m}$ (Fig. 3(A)).

\section{Biological characteristics}

Picocyanobacterial abundance ranged from $1.42 \times 10^{4}$ to $1.62 \times 10^{5}$ cells. $\mathrm{mL}^{-1}$ (Table 2). The highest concentrations $\left(1.62 \times 10^{5}\right.$ cells. $\left.\mathrm{mL}^{-1}\right)$ were observed in winter 2010 along the water column, and the peaks were detected at surface and $5 \mathrm{~m}$, respectively. The vertical distributions of picocyanobacteria displayed a similar profile each year, and abundances tended to decrease with depth. Concentrations of picocyanobacteria showed smaller vertical variations in November, December and January in 2009 and in 2010 than during the other months, in association with the absence of thermal stratification at these periods (Fig. 3(B)). The mean concentrations of heterotrophic bacteria reached $1.11 \times 10^{5}$ and $7.65 \times 10^{6}$ cells $\mathrm{mL}^{-1}$ in spring 2009 and 2010, respectively. The lowest abundance was detected in summer 2009 $\left(3.33 \times 10^{5}\right.$ cells $\left.\mathrm{mL}^{-1}\right)$. In spring 2009; a peak (with $2.02 \times 10^{7}$ cells $\mathrm{mL}^{-1}$ ) was detected at $5 \mathrm{~m}$. The vertical distributions of heterotrophic bacteria showed important fluctuations during the period of study (Fig. 3(C)). This community was characterized by a clear separation between high-DNA (HDNA) and low-DNA (LDNA) content populations. LDNA and HDNA abundances ranged between $1.32 \times 10^{5}$ and $4.03 \times 10^{7}$ cells. $\mathrm{mL}^{-1}$ and between $5.92 \times 10^{4}$ and $2.13 \times 10^{7}$ cells. $\mathrm{mL}^{-1}$, respectively. The proportion fluctuated between 4.5 and $69.4 \%$ and the highest and lowest percentages for HDNA and LDNA were observed in summer and spring 2010, 

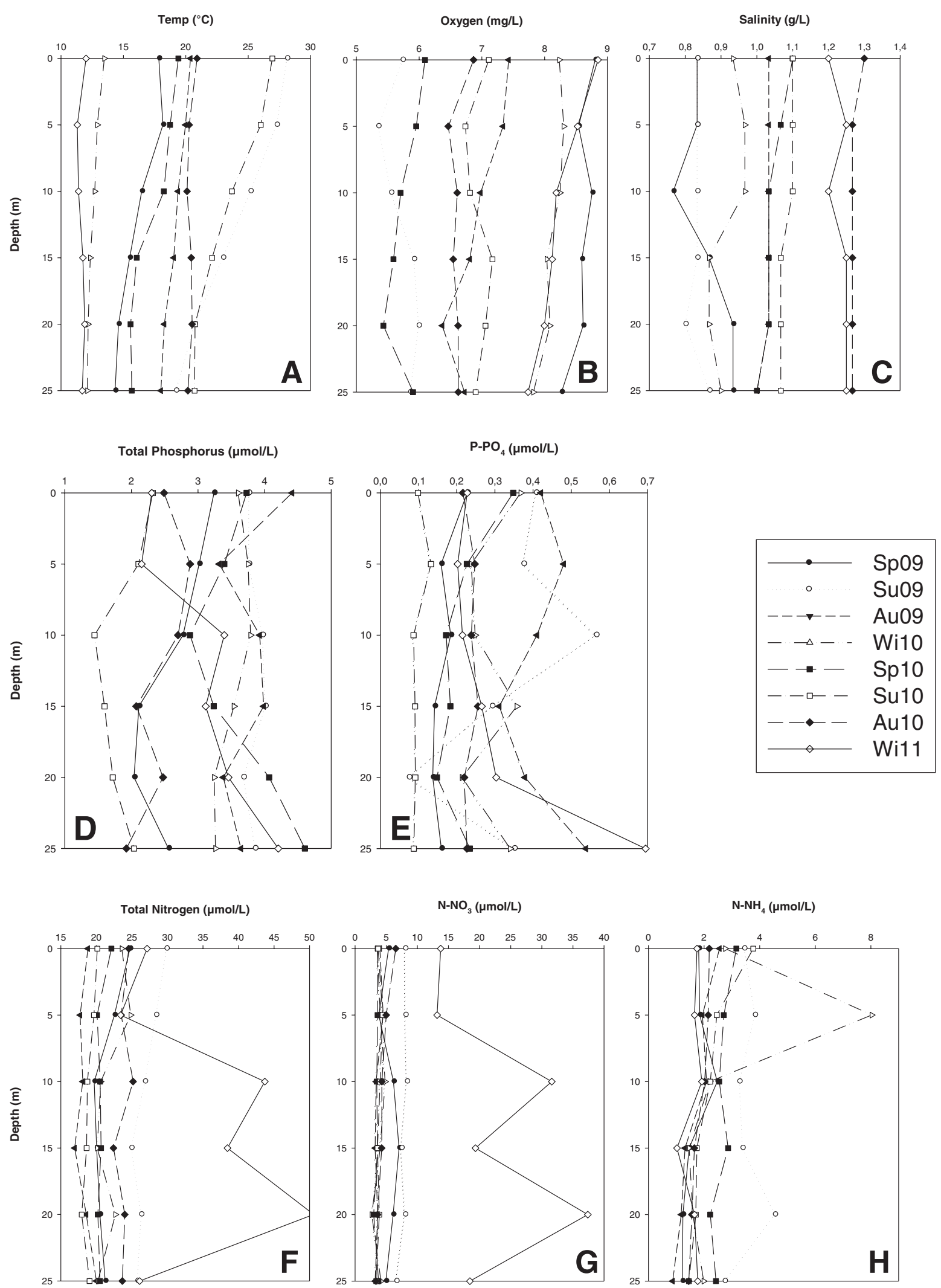

Fig. 2. Vertical profiles of the different hydrological parameters measured in the Sidi Salem reservoir throughout the period of the study. Sp, spring; Su, summer; Au, autumn; Wi, winter. 

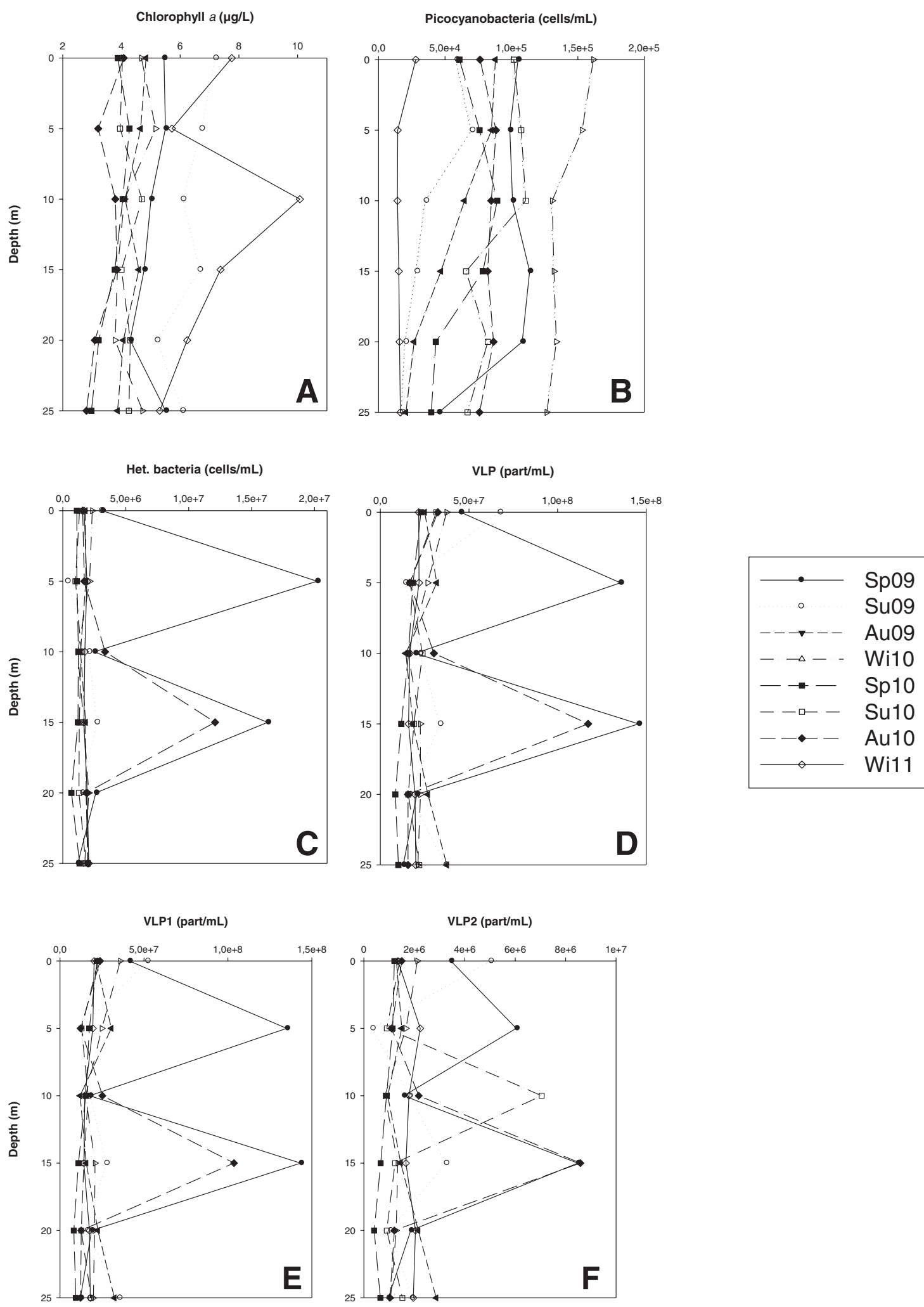

Fig. 3. Vertical profiles of the different biological parameters measured in the Sidi Salem reservoir throughout the period of the study. $\mathrm{Sp}$, spring; Su, summer; $\mathrm{Au}$, autumn; $\mathrm{Wi}$, winter.

respectively (Fig. 4). The concentration of the most abundant VLP group, i.e., VLP1, ranged between $8.13 \times 10^{6}$ and $1.43 \times 10^{8}$ part. $\mathrm{mL}^{-1}$. The concentration of VLP2 was always lower, and ranged between $3.28 \times 10^{5}$ and $8.59 \times 10^{6}$ part. $\mathrm{mL}^{-1}$. The values of VLP3 were even lower than VLP2 and ranged between $7.9 \times 10^{3}$ and $1.89 \times 10^{6}$ part $\mathrm{mL}^{-1}$. Total VLP concentrations varied from $8.43 \times 10^{6}$ to $1.46 \times 10^{8}$.part. $\mathrm{mL}^{-1}$. The abundance 

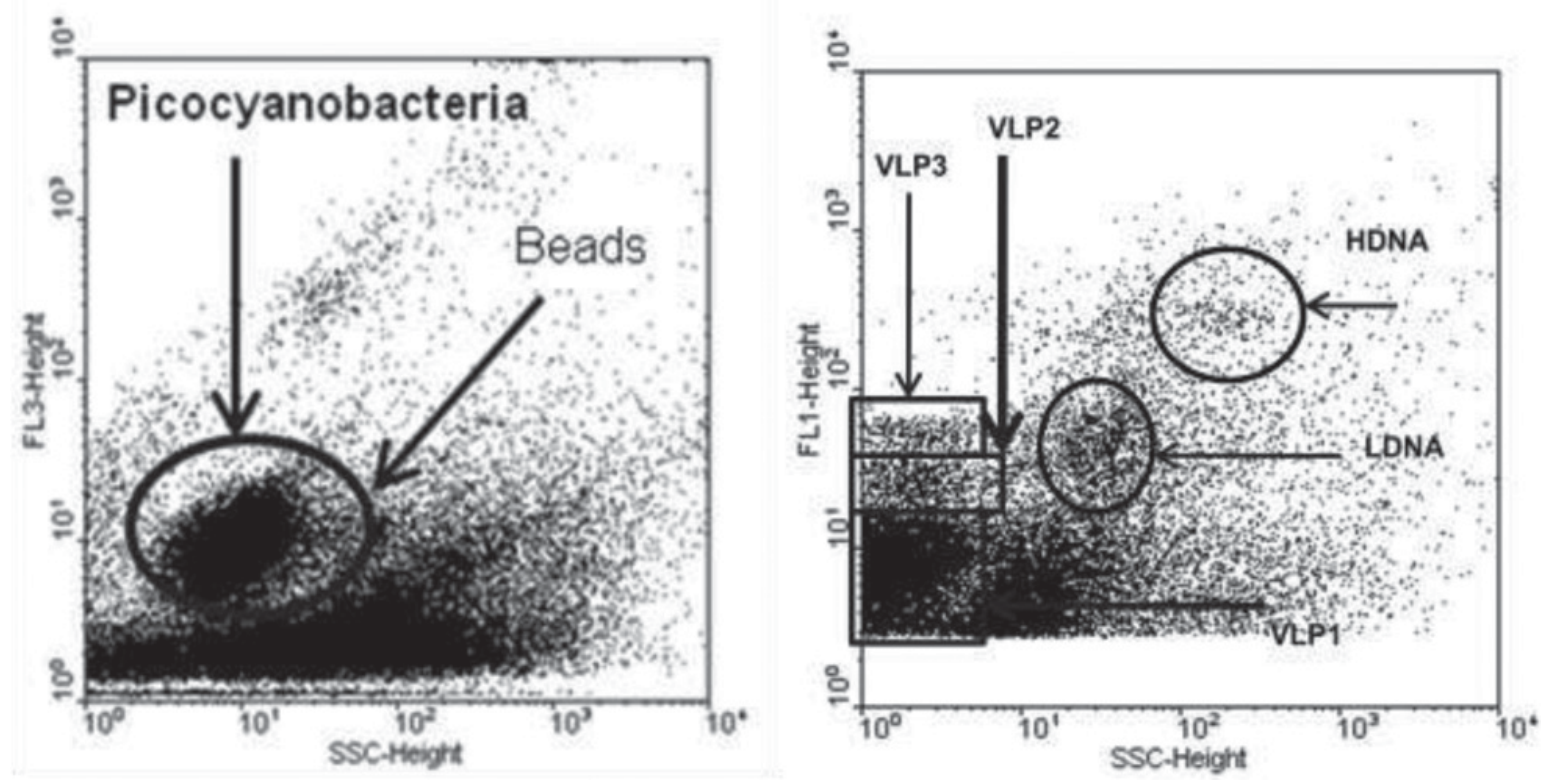

Fig. 4. FCM Cytograms showing the different microbial communities.

of viruses, showed an increase in April 2009, with a peak $\left(1.46 \times 10^{8}\right.$ part. $\left.\mathrm{mL}^{-1}\right)$ at $5 \mathrm{~m}$ (Fig. 3(D)-(F)). Like the heterotrophic bacteria, the VLP community was highly dynamic. The virus-to-prokaryotic ratio used as a proxy of virus-prokaryote interactions varied between 56.3 and 99.3. The highest values were observed during February 2009 at $25 \mathrm{~m}$. On average the VPR was 22 and the mean values calculated for each month ranged varied between 8 and 109.

\section{Relationships between variables}

The various environmental and biological factors showed significant seasonal variations. ANOVA analysis showed that the abundances of viruses, bacteria and picocyanobacteria changed markedly with season and depths. The picocyanobacteria distribution through the water column was not homogeneous; their abundance decrease with depth in spring 2009, summer and autumn 2009. The high abundance of bacteria and virus was detected in the euphotic zone in the summer, spring and autumn, respectively (Table 3). The seasonal succession of the selected microorganisms showed a significant variation observed in the layer $20 \mathrm{~m}$ in all season. However, the abundance of picocyanobacteria was important in the summer 2009 and autumn 2010 in $5 \mathrm{~m}$ depth. There was any significant distribution of bacteria and virus in the surface and $5 \mathrm{~m}$ depth in all season, but a significant abundance of bacteria marked in summer 2009 at $10 \mathrm{~m}$.Viral abundance was significant in winter and autumn at $20 \mathrm{~m}$ (Table $4 \mathrm{a}$ and $4 \mathrm{~b}$ ).

To describe the relationships between the selected microorganisms and others parameters we used Pearson linear correlations based on spatial analyses (Table 5). A significant correlation was found between the bacteria and the viruses (VLP) considered all together $(r=0.94$, $P<0.0001)$ but also with VLP1 and VLP2 considered thus separately $(r=0.80, P<0.001 ; r=0.78, P<0.001)$. An inverse relationship between the VPR and bacterial abundance was recorded with the highest VPR values recorded at times of relatively low bacterial abundance. A weak correlation was observed between $\mathrm{pH}$ and VLP2 $(r=0.56, P<0.05)$. The picocyanobacteria were highly correlated with temperature, oxygen, ammonium and chlorophyll $a(r=0.94, P<0.0001 ; r=0.85, P<0.001$; $r=0.87, P<0.001 ; r=0.83, P<0.001)$. At last, a positive relationship was observed between chlorophyll $a$, temperature and oxygen $(r=0.88, \quad P<0.001 ; \quad r=0.84$, $P<0.001)$. There was no relationship between the viruses and the autotrophs.

The PCA discriminated two groups around the F1 and F2 axes. F1 explained $36.9 \%$ of the variability and positively selected the group G1, mainly composed by the picocyanobacteria, chlorophyll $a$, dissolved oxygen, temperature and $\mathrm{pH}$. F2 represented $29.8 \%$ of the variability and negatively selected the group G2, constituted by bacterial and viral groups. In addition the statistical analysis revealed that microbial community abundance was more important in the upper lit layers (Fig. 5).

\section{Discussion}

This study showed that the Sidi Salem's reservoir is characterized by a thermal stratification which associated with dissolved oxygen one; the hypolimnion is relatively well oxygenated and has no total anoxia period, even in summer, although the gradient is most pronounced when the stratification is stable. The amount of chlorophyll $a$, reveals two algal development periods (spring and autumn). The evolution of physicochemical parameters is 


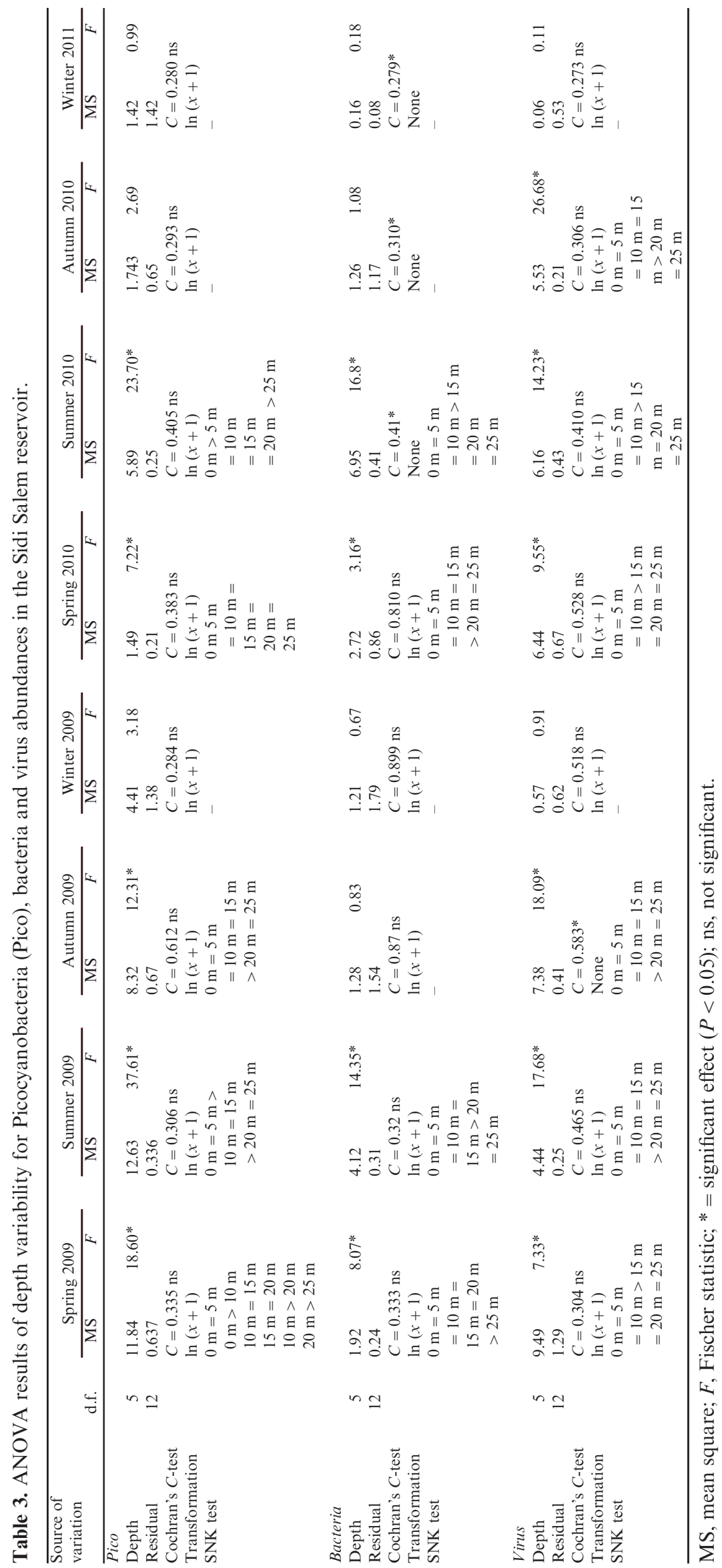




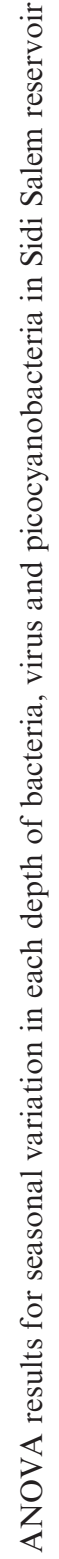

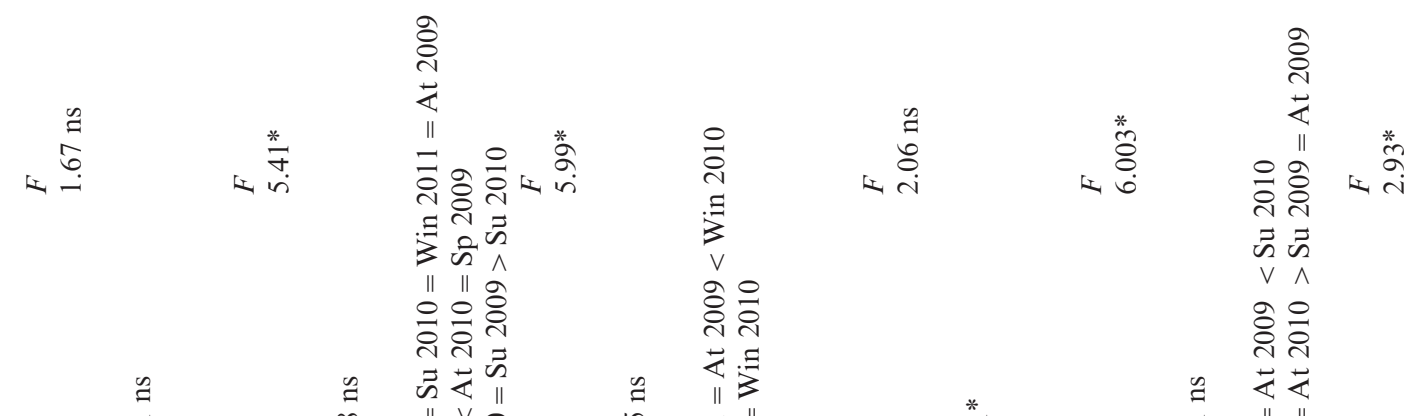

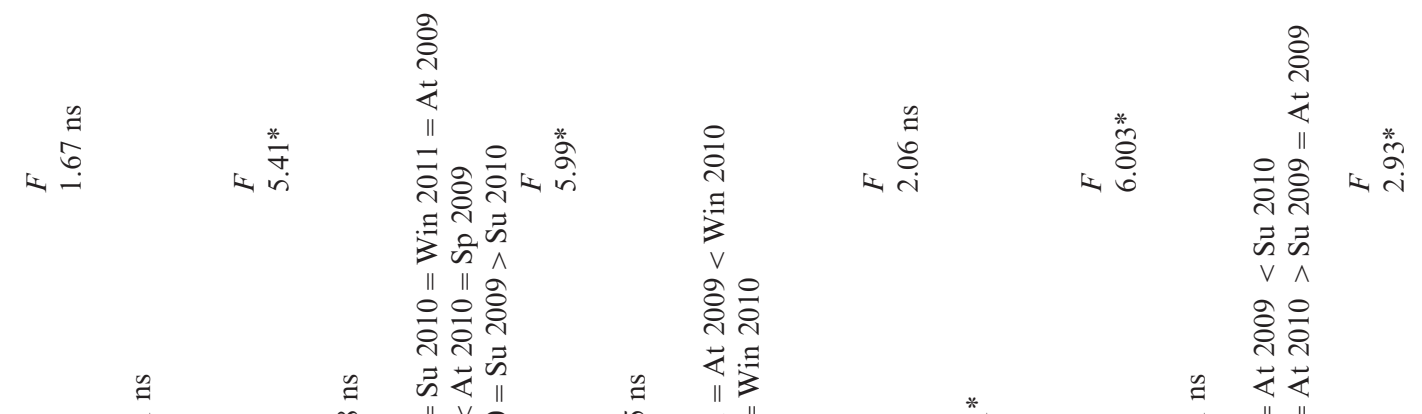

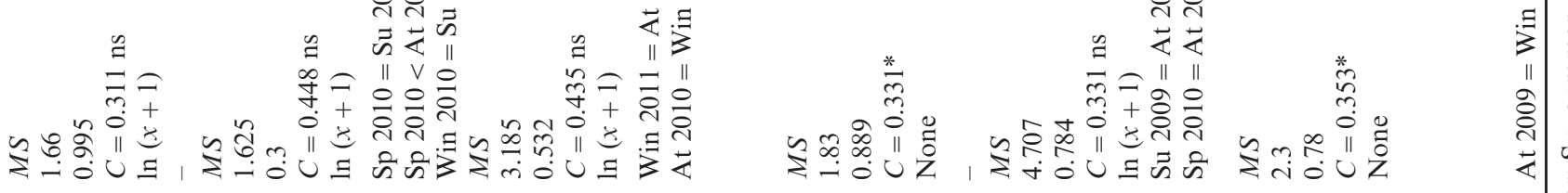

stons

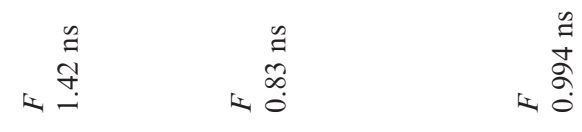

象

شإ.

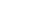

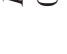

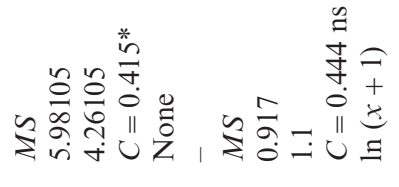

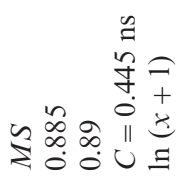

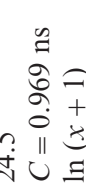

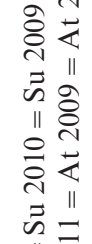

$1-$

$4-$

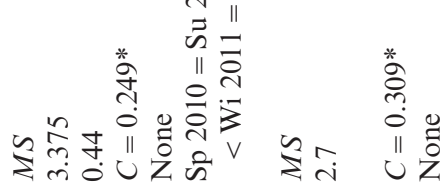

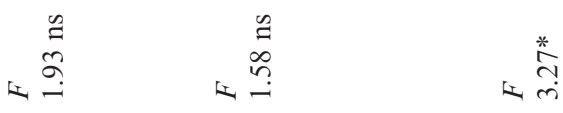

ڤे ڤ્ণ

ज艺

느응

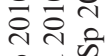

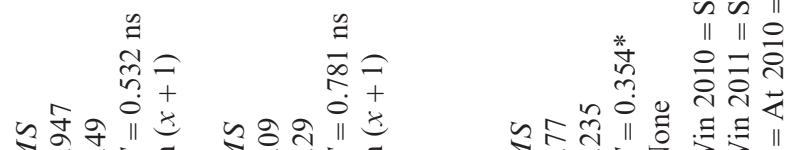

की के की

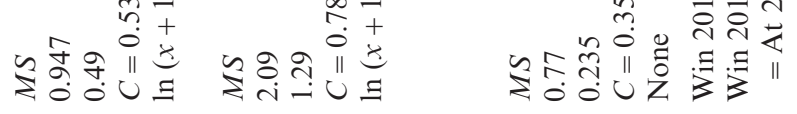

$\underset{*}{\stackrel{*}{\sigma}}$

近

i

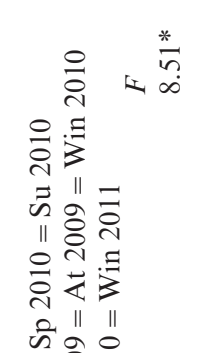

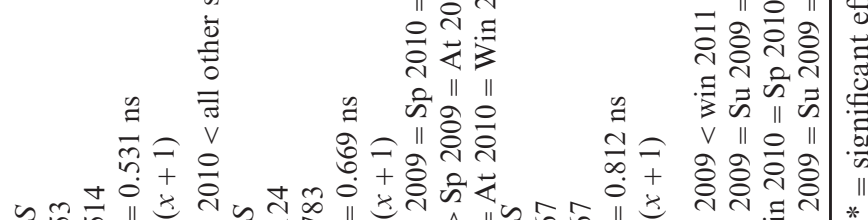

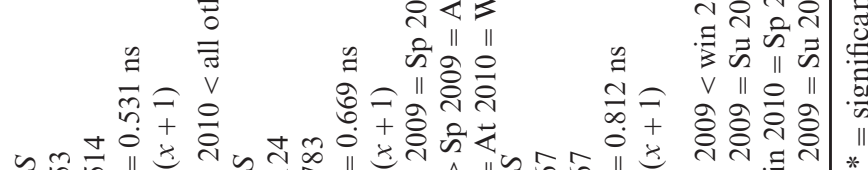

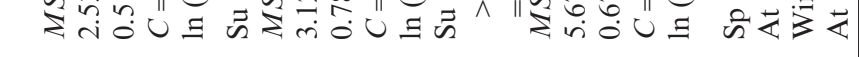

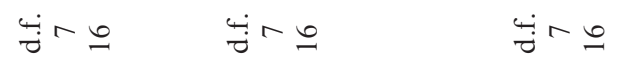

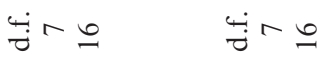

ți

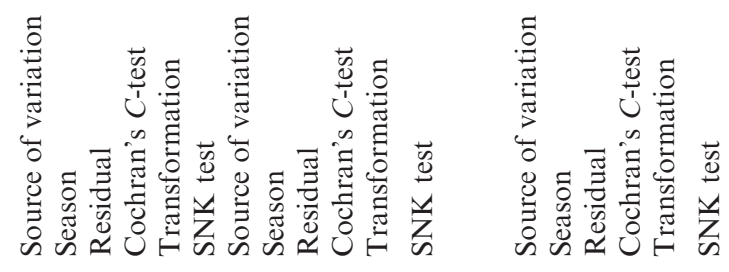

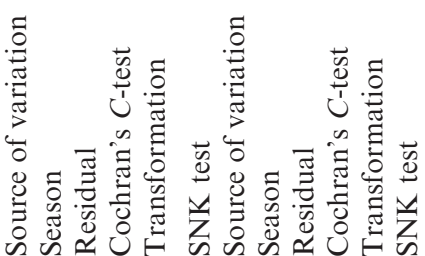

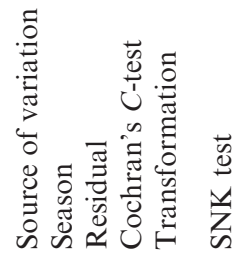

I

$\stackrel{\Xi}{\varrho}$

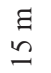

ฐ 
Table 5. Correlation matrix (Pearson test) for physical, chemical and biological variables sampled/analysed in the reservoir of Sidi Salem during 2 years of monitoring $(* P<0.05, * * P<0.001, * * * P<0.0001)$.

\begin{tabular}{|c|c|c|c|c|c|c|c|c|c|c|c|c|c|}
\hline & $\mathrm{T}^{\circ} \mathrm{C}$ & $\overline{\mathrm{pH}}$ & $\overline{\mathrm{O}_{2}}$ & Salinity & $\overline{\mathrm{PO}_{4}}$ & $\mathrm{NH}_{4}^{+}$ & $\overline{\mathrm{NO}_{3}^{-}}$ & $\overline{\mathrm{SIO}_{2}}$ & chla & Bacteria & Picocyano & VLP1 & VLP2 \\
\hline$\overline{\mathrm{T}^{\circ} \mathrm{C}}$ & 1 & 0.444 & $0.900 * * *$ & 0.247 & -0.045 & $0.918 * * *$ & -0.287 & -0.166 & $0.888 * *$ & 0.129 & $0.944 * * *$ & 0.067 & 0.174 \\
\hline $\mathrm{pH}$ & & 1 & $0.743 * *$ & -0.342 & -0.443 & 0.152 & 0.231 & $-0.594 \%$ & $0.454 \%$ & 0.221 & $0.548 *$ & 0.111 & $0.566 *$ \\
\hline $\mathrm{O}_{2}$ & & & 1 & 0.133 & -0.075 & $0.681 * *$ & -0.161 & -0.430 & $0.842 * *$ & 0.044 & $0.853 * *$ & 0.065 & 0.293 \\
\hline Salinity & & & & 1 & $0.454 *$ & 0.391 & $-0.680 *$ & 0.260 & -0.027 & -0.285 & -0.027 & 0.088 & $-0.580 *$ \\
\hline $\mathrm{PO}_{4}^{-}$ & & & & & 1 & -0.129 & $-0.642 *$ & -0.311 & 0.172 & -0.277 & -0.332 & 0.265 & -0.120 \\
\hline $\mathrm{NH}_{4}^{+}$ & & & & & & 1 & -0.295 & 0.199 & $0.687 * *$ & 0.119 & $0.872 * *$ & -0.027 & -0.076 \\
\hline $\mathrm{NO}_{3}^{-}$ & & & & & & & 1 & 0.308 & -0.256 & -0.333 & -0.013 & $-0.737 * *$ & -0.126 \\
\hline $\mathrm{SIO}_{2}^{-}$ & & & & & & & & 1 & -0.459 & -0.370 & -0.099 & $-0.628 * *$ & $-0.799 * *$ \\
\hline Chla & & & & & & & & & 1 & 0.156 & $0.834 * *$ & 0.161 & $0.422 *$ \\
\hline Bacteria & & & & & & & & & & 1 & 0.215 & $0.804 * *$ & $0.779 * *$ \\
\hline Picocyano & & & & & & & & & & & 1 & -0.038 & 0.265 \\
\hline VLP1 & & & & & & & & & & & & 1 & $0.689 * *$ \\
\hline VLP2 & & & & & & & & & & & & & 1 \\
\hline
\end{tabular}

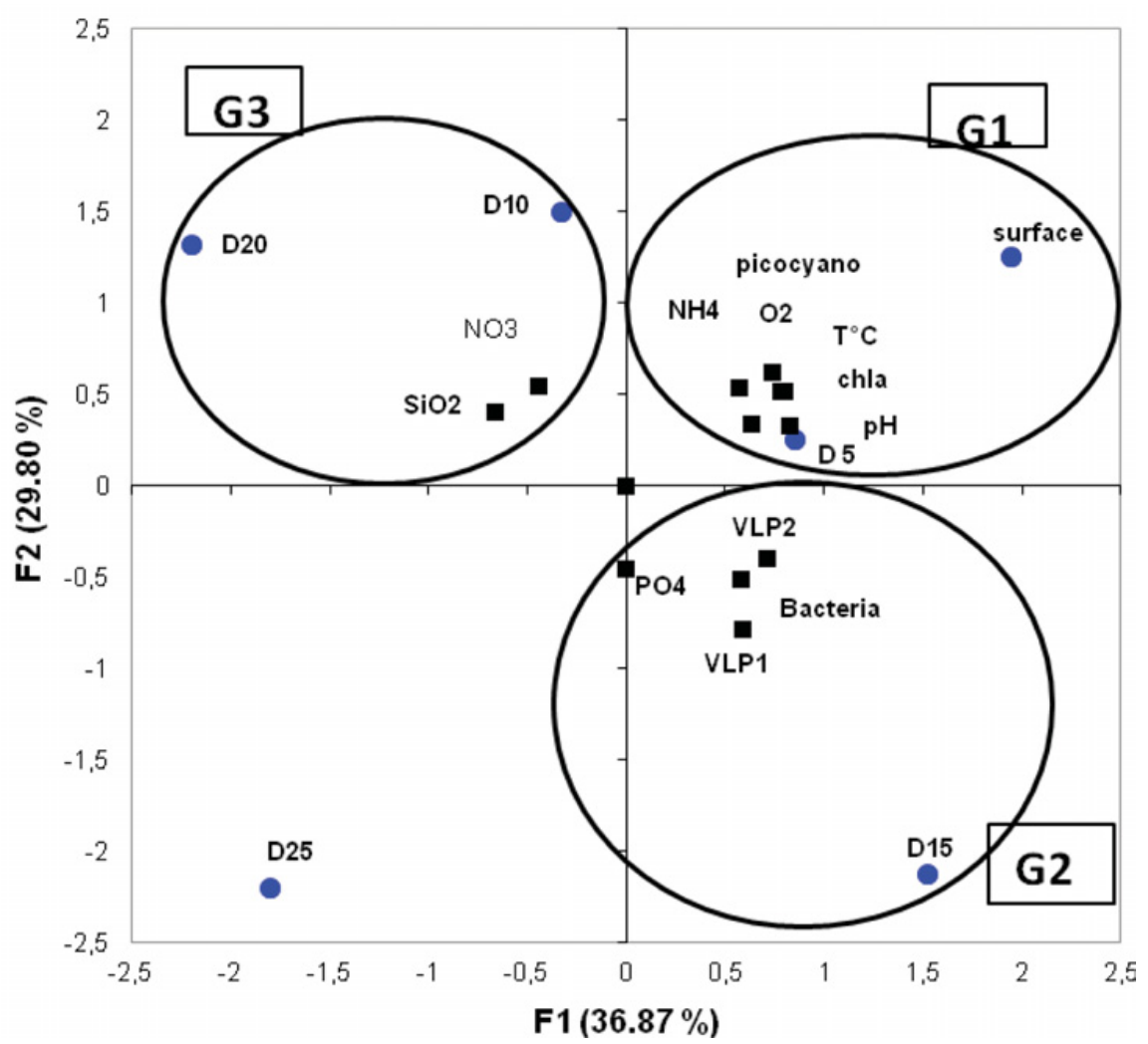

Fig. 5. PCA of the microbial communities with environmental variables throughout the water column in the Sidi Salem dam. D, depth; $\mathrm{G}$, group.

mainly regulated by the hydrodynamic character of the reservoir's waters which leads to a relatively frequent mixing.

According to Ryding and Rast (1994), the values of TP, chlorophyll $a$ and transparency indicate that Sidi Salem reservoir oscillated between a mesotrophic and eutrophic status. It was clear; that the deduction of dam Mediterranean area is subjected to high climate and anthropic pressures, and that the diagnosis of their trophic state will have imperatively gone through a model that will be more adapted. The same results were found by Mouelhi et al. (2000). This does not correlate with the study of Sellami et al. (2012) concluding that the reservoir of Sidi Saâd oscillated between oligotrophic and mesotrophic levels. As well, our result does not corroborate with the result of Ben Rejeb Jenhani et al. (2012) showing that the reservoir of Bir M'cherga can be considered as hypertrophic.

In our survey, the ratio $\mathrm{N} / \mathrm{P}$ was higher, which reflects an excess of nitrogen to phosphorus. The significant finding of this ratio shows that, in addition to the apparent limitation of phosphorus added the nitrogen, phosphorus 
is the most frequently limiting factor in freshwater and in various eutrophic lakes. Phosphorus limitation is gradually replaced by a nitrogen limitation in late summer. The same results were obtained in many studies of reservoirs in Tunisia (Ben Rejeb Jenhani et al., 2006; El Herry et al., 2008; Sellemi et al., 2009).

Researcher have documented that the picocyanobacteria group presented the lowest abundance in winter and showed positive correlation between cell number and water temperature, which indicated the influence of thermal stratification on their growth (Wang et al., 2009). In addition, picocyanobacteria distribution increased in the metalimnion of the reservoir. The complex variability of community structure is related to the spectrum of environmental variability, through the modulation of intrinsic factors (basin morphometry, thermal stratification and wind mixing) and such external influences as fluctuating supply of nutrients (Harris, 1980). Nevertheless, abiotic factors (temperature, precipitation) provide the primary force that drives temporal variability in species abundance, before even competitive interactions (Houlahan et al., 2007). Our result was corroborated with several researches' concluding that the thermal conditions were significant not only for the ambient water temperature but for the maintenance of a density gradient resisting settlement and extension of the picophytoplankton peak. Elsewhere, the peaks of abundance in vertical distribution of picophytoplankton have been observed, variously in the lower metalimnion and upper hypolimnion of lakes Huron and Michigan (Fahnenstiel and Carrick, 1992) and also of lake Stechlin (Padisák et al., 1998, 2003); in the metalimnion, beneath the steepest part of the thermocline in lake Constance and lake Maggiore (Weisse and Schweizer, 1991; Callieri and Pinolini, 1995); in the metalimnion of lake Baikal (Nagata et al., 1994). Picocyanobacteria showed a negative correlation with depth, this may reflect the importance of light quality on their growth (Voros et al., 1998). Moreover, light is known to be an important factor in niche differentiation of picocyanobacteria. As well, water column depth, which is roughly inversely related to the trophic state of the lake, is an important indicator of the presence of picophytoplankton and/or of its abundance relative to large species of phytoplankton (Callieri, 2007).

Nutrient supply is an important factor affecting the picophytoplankton distributions (Stockner and Shortreed, 1994; Vrede et al., 1999). Picocyanobacteria exhibited a negative correlation with $\mathrm{PO}_{4}^{3-}$ in this reservoir, revealing that high phosphate concentration decreases picocyanobacterial growth rates (Schallenberg and Burns, 2001). However, high phosphate cannot constrain the picocyanobacteria growth at higher water temperature mainly in summer, suggesting that there are multi-factors in controlling picocyanobacteria abundance. Other factors such as grazing by ciliates (Chang et al., 2003) or other microzooplankton, viral infections and co-sedimentation with organic particles (Fuhrman, 1999; Waite et al., 2000) may also affect the picophytoplankton distributions. In our study, the presence of picocyanobacteria was important and abundant mainly in spring and early summer, when the thermal stratification and clear water phase took place. This corroborates the results found by several authors (Anneville and Leboulanger, 2001; Jacquet et al., 2005; Cellamare et al., 2010) in their research. Recently, it is well known that nutrient availability, sedimentation, and grazing were considered the major driving forces of microbial and algal communities in aquatic environments (Tijdens et al., 2008). The picophytoplankton abundance and biomass increase and its relative importance decreases with the increase of trophic state in the freshwater system (Szelag-Wasielewaska, 1999; Stockner et al., 2000; Bell and Kalff, 2001; Callieri and Stockner, 2002). Light and water temperature are also two important factors controlling picophytoplankton growth (Wehr, 1993; Agawin et al., 2000; Wakabayashi and Ichise, 2004). As well the viral population dynamics have been associated with environmental factors such as seasonality, location, water depth, degree of stratification, tide height, salinity and chlorophyll $a$ concentration (Wommack et al., 1999; Frederickson et al., 2003; Short and Suttle, 2003; Dorigo et al., 2004). Moreover, the picocyanobacteria, presented a maximum abundance with thermal stratification in March 2009 and June 2010 in our meso-eutrophic lake. In agreement with the literature, picocyanobacteria are present in lakes of different trophies, but they are likely to be the dominant group all year long in the oligotrophic system while they took advantage of the low nutrient concentrations found in surface waters in spring and summer in mesotrophic lakes (Weisse, 1993; Callieri, 2007). Compared to marine, there is less information available on freshwater picocyanobacterial biodiversity, and the factors controlling the growth, distribution and productivity (Stockner and Antia, 1986; Callieri and Stockner, 2002). Similar to marine, freshwater picocyanobacteria show high diversity with specific niche adaptation and the abundance of freshwater Synechococcus follows a seasonal pattern with a peak in spring after winter mixing and a peak late summer (Weisse, 1993; Stockner et al., 2000; Callieri and Stockner, 2002).

The flow cytometer (FC) allowed us to easily differentiate different groups within these microbial components, using scatter plots of either natural fluorescence (in the case of phytoplankton), or an added chemical dye such as SYBER Green I that binds to nucleic acid (in the case of bacteria and viruses) versus side scatter. Particles with similar fluorescence and side scatter properties form an individual group on a scatter plot, allowing different groups of microorganisms to be distinguished (Chisholm et al., 1986; Marie et al., 1999). In the present study, two distinct groups of bacteria marked by their high and low DNA fluorescence upon staining with SYBER Green I. The HDNA bacteria have often been considered to represent the active fraction (Vaque et al., 2001; Lebaron et al., 2002). The distribution of the two groups in this study was very similar; our results are very similar to data shown by Li and Dickie (2001), which enumerated bacteria from the surface of coastal waters over successive annual cycles and found that the patterns of seasonal 
Table 6. Comparison of viral, bacterial and picocyanobacteria abundance reported in some freshwater lake with different trophic status.

\begin{tabular}{|c|c|c|c|c|c|}
\hline Lake and location & Trophic status & $\begin{array}{l}\text { Picocyanobacteria } \\
\left(10^{4} \text { cells. } \mathrm{mL}^{-1}\right)\end{array}$ & $\begin{array}{c}\text { Heterotrophic } \\
\text { bacteria } \\
\left(10^{6} \text { cells. } \mathrm{mL}^{-1}\right)\end{array}$ & $\begin{array}{c}\text { Virus } \\
\left(10^{6} \text { part. } \mathrm{mL}^{-1}\right)\end{array}$ & References \\
\hline Alte Donau, Austria & Eutrophic & - & - & $17-117$ & Fisher and Velmirov (2002) \\
\hline Constance, Germany & Mesotrophic & 9.5 & - & $10-40$ & Hennes and Simon (1995) \\
\hline Pavin, France & Oligo-mesotrophic & 10.7 & - & $10-54$ & $\begin{array}{l}\text { Carrias et al. }(1996) \\
\text { Bettarel et al. }(2003,2004)\end{array}$ \\
\hline Lemam, France & Mesotrophic & 2.9 & 2.6 & 52 & Personnic et al. (2009) \\
\hline Bourget, France & Mesotrophic & 2.7 & 2.7 & 64 & Personnic et al. (2009) \\
\hline $\begin{array}{l}\text { Allal El Fassi reservoir, } \\
\text { Maroc }\end{array}$ & Mesotrophic & 1.7 & 5.4 & - & Rachiq et al. (2002) \\
\hline $\begin{array}{l}\text { Sidi Salem Reservoir, } \\
\text { Tunisia }\end{array}$ & Meso-eutrophic & 8.9 & 7.6 & 67 & $\begin{array}{l}\text { Ben Romdhane et al., } \\
\text { present study }\end{array}$ \\
\hline
\end{tabular}

abundance were very similar for both groups. Bacterial abundance in Sidi Salem's reservoir was high, with concentration reaching $\left(5.26\right.$ and $3.84 \times 10^{7}$ cells. $\left.\mathrm{mL}^{-1}\right)$. In our surveys, the Heterotrophic bacteria showed a negative correlation with chlorophyll $a$, their biomass is a well-known characteristic of the eutrophic system; the same result was obtained by Zhang et al. (2013) in the Pearl River Estuary. However, many investigators have observed significant correlations between bacteria and chlorophyll $a$ in various ecosystems, including the Chesapeake Bay (Ducklow et al., 1999), the Mississippi River Plume (Liu et al., 2004), the Danshui Estuary (Tsai et al., 2011), the East China Sea (Pan et al., 2005) and the northern South China Sea (Yuan et al., 2011), indicating that primary production provides most of the carbon needed for heterotrophic bacteria production in these settings. In many estuarine environments, however, the relationship between heterotrophic bacteria and primary production is weak or non-existent (Shiah and Ducklow, 1994; Kelley et al.,1998) because dissolved organic carbon is abundant or bacterial growth depends mostly on other non-phytoplanktonic sources of carbon (Fouilland and Mostajir, 2010). Bacterial production and chlorophyll $a$ measurements were shown to be significantly higher in the eutrophic basin of Lake Erie, Ohio, USA, than in the less productive basins (DeBruyn et al., 2004). The fluctuation of vertical distributions of heterotrophic bacteria during the study period, explained that the bacterial community composition varied in response to environmental parameters' changing, also with their different adaptations proliferating under a range of light conditions (Casamayor et al., 2000; Vila and Abella, 2001). Furthermore, it is generally accepted that phytoplankton, especially picofractioned phytoplankton, are the principal source of organic carbon for bacteria (Baines and Pace, 1991).

As regards virioplankton, the highest abundances were observed in surface waters. This viral peak followed the increase in bacterial abundance at the same period as reported in other ecosystems. It was mentioned before by several authors, in Alpine lakes (Personnic et al., 2009), in seawater (Bergh et al., 1989), the Chesapeake Bay (Wommack et al., 1992), the Tampa Bay (Cochlan et al., 1993), the Northern Adriatic Sea (Weinbauer and Peduzzi, 1995), the backwater system of the Danube River (Mathias et al., 1995), the alkaline and hypersaline Mono lake (Brum et al., 2005) and in Norwegian coastal waters (Bratbak et al., 1996). In addition, such high values, especially for VLP1, recorded throughout the water column, were clearly associated with water column mixing, probably because bacteria were stimulated by both organic and inorganic nutrients (Personnic et al., 2009). The highest ratios (VPR) that were found in summer and in deeper waters could also suggest a higher impact of viruses in bacteria when compared to surface waters, previously reported by several authors (Weinbauer and Hofle, 1998; Colombet et al., 2006). Seasons in which a high VBR occurred could be expected to display greater virioplankton production and more bacterioplankton lysis. It is clear that VBR is only an indicator used to investigate possible relationships between viruses and their bacterial or phytoplankton hosts, so that it is clearly insufficient to infer the importance of the role (lytic effects) played by the viruses; as described by many authors (Wilson and Mann, 1997; Weinbauer and Rassoulzadegan, 2004; Abedon, 2006). In addition, our meso-eutrophic reservoir presented the higher abundances of picocyanobacteria, bacteria and viruses which represented $\left(8.910^{4}, 7.6 \times 10^{6}\right.$ and $67 \times 10^{6}$ part. $\left.\mathrm{mL}^{-1}\right)$, respectively; compared with mesotrophic lake Bourget and Lemam (Personnic et al., 2009) and mesotrophic reservoir Allal El Fassi (Rachiq et al., 2002). However, our study reported the lower abundances of picocyanobacteria than showed by Hennes and Simon (1995). In their study, they have reported in mesotrophic Lake Constance that the abundances of viruses ranged from $\left(10^{-4} 7 \times 10^{6}\right.$ part.mL $\left.\mathrm{m}^{-1}\right)$, the similar results were also reported by Simek et al. (2001) in meso-eutrophic Rimov reservoir (Table 6).

Based on side scatter and green DNA dye complex fluorescence, FCM data allowed us to distinguish three 
groups of viruses. Other studies also reported such discrimination (Castberg et al., 2001; Chen et al., 2001; Jacquet et al., 2002; Goddard et al., 2005; Duhamel and Jacquet, 2006). The abundance of VLP1 was higher than the abundance of VLP2 and also than the abundance of VLP3. Published works by different authors (Marie et al., 1999; Wommack and Colwell, 2000; Larsen et al., 2001; Culley and Welschmeyer, 2002; Payet and Suttle, 2008 ) indicate that most of what we called the VLP1 group is likely to consist of bacteriophages. Using statistical analysis, we found a significant correlation between heterotrophic bacteria and virioplankton. However, we did not find any significant correlation between viral abundance and chlorophyll $a$ concentrations. In contrast, VLP2, which we had thought was more specific to phytoplanktonic or cyanobacterial viruses, was observed to be significantly linked to chlorophyll $a(r=0.41, P<0.05)$. These results, suggesting firstly that phytoplankton viruses do not contribute significantly to the total virus pool, and secondly that the positive effect of an increase in chlorophyll $a$ on heterotrophic bacteria is not directly beneficial to virus production(Personnic et al., 2009).

This is the first report of analytical flow cytometry (AFC) which was used as the tool choice to determine concentration of different groups within the whole microbial community, from viruses and bacteria, through to phytoplankton essentially the picocyanobacteria of the surface water in Tunisia. The selected microorganisms played a very important role in maintaining particular ecosystem structures and functions in the freshwater lake; however, very few studies have been conducted on the characteristics of the components in the microbial, viral and planktonic communities in the retentions. In the current study, we simultaneously observed the distribution patterns and biomass levels of heterotrophic bacteria, virus and picocyanobacteria. Their biomass was important in the upper water column. No significant correlations were found between nutrients, bacterial and viral groups. However, picocyanobacteria have a significant correlation with temperature, oxygen and chlorophyll $a$.

Acknowledgements. We would like to express our gratitude to everyone who has contributed to the elaboration of the present investigation. We thank the anonymous referees for the helpful advice and comments. This study was supported by the Tunisian Ministry of Scientific Research and Technology.

\section{References}

Abedon S.T., 2006. Phage ecology. In: Abedon C.S.T. (ed.), The Bacteriophages, Oxford University Press, Oxford, 37-46.

Agawin N.S.R., Duarte C.M. and Agustí S., 2000. Nutrient and temperature control of the contribution of picoplankton to phytoplankton biomass and production. Limnol. Oceanogr., $45,591-600$.

Anneville O. and Leboulanger C., 2001. Long-terms changes in the vertical distribution of phytoplankton biomass and primary production in Lake Geneva: a response to the oligotrophication. Atti. Assoc. Ital. Oceanol. Limnol., 14, 25-35.

Auguet, J.C., Barberan, A. and Casamayor, E.O., 2010. Global ecological patterns in uncultured archaea. ISME J. 4, 182-190.

Baines S.B. and Pace M.L., 1991. The production of dissolved organic matter by phytoplankton and its importance to bacteria: patterns across marine and freshwater system. Limnol. Oceanogr., 36, 1078-1090.

Bell T. and Kalff J., 2001. The contribution of picophytoplankton in marine and freshwater systems of different trophic status and depth. Limnol. Oceanogr., 46, 12431248.

Ben Mammou, A., 1998. Barrages Nebraska, Sidi Salem, Sidi Saâd et Sidi Boubaker. Quantification, étude sédimentologique et géotechnique des sédiments piégés. Apports des images satellitaires. Thèse Doct. Univ. Tunis, II, $345 \mathrm{p}$.

Ben Mammou A. and Louati M.H., 2007. Evolution temporelle de l'envasement des retenues de barrages de Tunisie. Rev. Sci. Eau, 20, 201-211.

Ben Rejeb Jenhani A., Bouaïcha N., El Herry S., Fathalli A., Zekri I., Haj Zekri S., Limam L., Alouini S. and Romdhane M.S., 2006. Les cyanobactéries et leurs potentialités toxiques dans les retenues des barrages du Nord de la Tunisie. Archs. Inst. Pasteur Tunis, 83, 71-81.

Ben Rejeb Jenhani A., Fathalli A. and Romdhane M.S., 2012. Phytoplankton assemblages in Bir M'Cherga freshwater reservoir (Tunisia). Water Resour. Wetlands, 136-141.

Benzarti Z., 2003. La pluviométrie en Tunisie: Analyse des années très pluvieuse. In: Arnould P. and Hotyat M. (eds.), Eau et environnement: Tunisie et milieux méditerranéens, ENS Edition, Lyon, 63-78.

Berdjeb, L., Pollet, T., Domaizon, I. and Jacquet, S., 2011. Effects of grazers and viruses on bacterial community structure and production in two contrasting trophic lakes. BMC Microb., 11, 1-18.

Bergh O., Borsheim K.Y., Bratbak G. and Heldal M., 1989. High abundance of viruses found in aquatic environments. Nature, 340, 467-468.

Bettarel Y., Sime-NGando T., Amblard C., Carrias J.-F. and Portelli C., 2003. Virioplankton and microbial communities in aquatic systems: a seasonal study in two lakes of different trophy. Freshw. Biol., 48, 810-822.

Bettarel Y., Sime-NGando T., Amblard C. and Dolan J., 2004. Viral activity in two contrasting lake ecosystems. Appl. Environ. Microb., 70, 2941-2951.

Bratbak G., Heldal M., Thingstad T.F. and Tuomi P.I., 1996. Dynamics of virus abundance in coastal sea water. FEMS Microb. Ecol., 19, 263-269.

Breitbart M., 2012. Marine viruses: truth or dare. Annu. Rev. Mar. Sci., 4, 425-448.

Brum J.R., Stewart G.F., Jiang S.C. and Jellison R., 2005. Spatial and temporal variability of prokaryotes, viruses, and viral infections of prokaryotes in an alkaline, hypersaline lake. Aqua. Microb. Ecol., 41, 247-260.

Brussaard C.P.D., 2004. Optimization of procedures for counting viruses by flow cytometry. Appl. Environ. Microb., 70, 1506-1513.

Callieri C., 2007. Picophytoplankton in freshwater ecosystems: the importance of small-sized phototrophs. Freshw. Rev., 1, 1-28 
Callieri C. and Pinolini M.L., 1995. Picoplankton in lake maggiore, Italy. Int. Rev. Gesamten. - Hydrobiol., 80, 491-501.

Callieri C. and Stockner J.G., 2002. Freshwater autotrophic picoplankton: a review. J. Limnol., 61, 1-14.

Carrias J.F., Amblard C. and Bourdier G., 1996. Protistan bacterivory in a oligo mesotrophic lake: importance of attached ciliates and flagellates. Microb. Ecol., 31, 249-268.

Casamayor E.O., Schafer H., Baneras L., Pedro-Alio C. and Muyzer G., 2000. Identification of and spatio-temporal differences between microbial assemblages from two neighboring sulfurous lakes: comparison by microscopy and denaturing gradient gel electrophoresis. Appl. Environ. Microb., 66, 499-508.

Castberg T., Larsen A., Sandaa R.A., Brussaard C.P.D., Egge J.K., Heldal M., Thyrhaug R., Van Hannen E.J. and Bratbak G., 2001. Microbial population dynamics and diversity during a bloom of the marine coccolithophorid Emiliania huxleyi (Haptophyta). Mar. Ecol. Prog. Ser., 221, 39-46.

Cellamare M., Rolland A. and Jacquet S., 2010. Flow cytometry sorting of freshwater phytoplankton. J. Appl. Phycol., 22, 87-100.

Chang J., Lin K.H., Chen K.M., Gong G.C. and Chiang K.P., 2003. Synechococcus growth and mortality rates in the East China Sea: range of variations and correlation with environmental factors. Deep Sea Res. II, 50, 1265-1278.

Chen F., Lu J.R., Binder B.J., Liu Y.C. and Hodson R.E., 2001. Application of digital image analysis and flow cytometry to enumerate marine viruses stained with SYBR gold. Appl. Environ. Microb., 67, 539-545.

Chisholm S.W., Armbrust E.W. and Olson R.J., 1986. The individual cell in phytoplankton ecology: cell cycles and applications of flow cytometry. In: Platt T. and Li W.K.W. (eds.), Photosynthetic Picoplankton. Can. J. Fish. Aqua. Sci. Ottawa, 343-369.

Clasen J.L., Brigden S.M., Payet J.P. and Suttle C.A., 2008. Evidence that viral abundance across oceans and lakes is driven by different biological factors. Freshw. Biol., 53, 1090-1100.

Cochlan W.P., Wilkner J., Steward G.F., Smith D.C. and Azam F., 1993. Spatial distribution of viruses, bacteria, chorophyll $a$ in neritic, oceanic and estuarine environments. Mar. Ecol. Prog. Ser., 92, 77-87.

Colombet J., Sime-Ngando T., Cauchie H.M., Fonty G., Hoffmann L. and Demeure G., 2006. Depth-related gradients of viral activity in Lake Pavin. Appl. Environ. Microb., 72, $4440-4445$.

Culley A.I. and Welschmeyer N.A., 2002. The abundance, distribution and correlation of viruses, phytoplankton and prokaryotes along a Pacific Ocean transect. Limnol. and Ocean., 47, 1508-1513.

Dauta A. and Feuillade J., 1995. Croissance et dynamique des populations algales. In: Pourriot R. and Meybeck M. (eds.), Limnologie générale, Masson, Paris Milan, Barcelone. Collec. Ecol. 328-350.

DeBruyn J.M., Leigh-Bell J.A., McKay R.M.L., Bourbonniere R.A. and Wilheim S.W., 2004. Microbial distributions and the impact of phosphorus on bacterial activity in Lake Erie. J. Great Lake Res. 30, 166-183.

Djemali I., Kraïem M.M., Cadic N., Porteau J.P., El Abed A. and Jarboui O., 2003. Evaluation de la biomasse piscicole en eau douce par echoprospection: application à la retenue de Sidi Salem. Bull. Inst. Natn. Sci. Tech. Mer Salammbô, 30, 23-32.

Dolédec S. and Chessel D., 1989. Rythmes saisonniers et composantes stationnelles en milieu aquatique. II. Prise en compte et élimination d'effets dans un tableau faunistique. Acta Oecol. Oec. Gen., 10, 207-332.

Dorigo U., Jacquet S. and Humbert J.F., 2004. Cyanophage diversity, inferred from 20 gene analyses, in the largest natural lake in France, Lake Bourget. Appl. Environ. Microb., 70, 1017-1022.

Ducklow H.W., Schultz G., Raymond P., Bauer J. and Shiah F.K., 1999. Bacterial dynamics in large and small estuaries. In: Bell C.R., Brylinsky M. and Johnson-Green P. (eds.), Microb. Ecol. of estua. - Atlan. Can, Society for Microb. Ecol., Halifax Canada, 105-111.

Duhamel S. and Jacquet S., 2006. Flow cytometric analysis of bacteria- and virus-like particles in lake sediments. J. Microb. Methods, 64, 316-332.

El Herry S., Fathalli A., Ben Rejeb Jenhani A. and Bouaïcha N., 2008. Seasonal occurrence and toxicity of Microcytis spp. and Oscillatoria tenuis in the Lebna Dam, Tunisia. Water Res., 42, 1263-1273.

Fahnenstiel G.L. and Carrick H.J., 1992. Phototrophic picoplankton in lakes Huron and Michigan: abundance, distribution, composition and contribution to biomass and production. Can. J. Fish. Aqua. Sci., 49, 379-388.

Fathalli A., Ben Rejeb Jenhani A., Romdhane M.S. and Bouaïcha N., 2006. Contribution à la caractérisation phytoplanctonique et écotoxicologique des eaux de la retenue de barrage Kasseb. Water, Waste and Environment Research, 6, 33-42.

Fischer U.R. and Velimirov B., 2002. High control of bacterial production by viruses in a eutrophic oxbow lake. Aqua. Microb. Ecol., 27, 1-12.

Fouilland E. and Mostajir B., 2010. Revisited phytoplanktonic carbon dependency of heterotrophic bacteria in freshwater, transitional, coastal and oceanic waters. FEMS - Microb. Ecol., 73, 419-429.

Frederickson C.M., Short S.M. and Suttle C.A., 2003. The physical environment affects cyanophage communities in British Columbia inlets. Microb. Ecol. 46, 348-357.

Fuhrman J.A., 1999. Marine viruses and their biogeochemical and ecological effects. Nature, 399, 541-548.

Fuhrman J.A. and Suttle C.A., 1993. Viruses in marine planktonic system. Oceanography, 6, 51-63.

Goddard V., Baker A.C., Davy J.E. et al., 2005. Temporal distribution of viruses, bacteria and phytoplankton throughout the water column in a freshwater hypereutrophic lake. Aquat. Microb. Ecol. 39, 211-223.

Harris G.P., 1980. Temporal and spatial scales in phytoplankton ecology. Mechanisms, methods, model and management. Can. J. Fish. Aqua. Sci., 37, 877-900.

Hennes K.P. and Simon M., 1995. Significance of bacteriophages for controlling bacterioplankton growth in a mesotrophic lake. Appl. Environ. Microb., 61, 333-340.

Herbland A., Le Bouteiller A. and Raimbault P., 1985. Size structure of phytoplankton biomass in the equatorial Atlantic Ocean. Deep Sea Res., 32, 819-836.

Houlahan J.E., Currie D.J., Cottenie K., Cumming G.S., Ernest S.K., Findlay C.S., Fuhlendorf S.D., Gaedke U., Legendre P., Magnuson J.J., McArdle B.H., Muldavin E.H., Noble D., Russell R., Stevens R.D., Willis T.J., Woiwod I.P. and 
Wondzell S.M., 2007. Compensatory dynamics are rare in natural ecological communities. Proc. Natl. Acad. Sci. USA, 104, 3273-3277.

Jacquet S., Heldal M., Iglesias-Rodriguez D., Larsen A., Wilson W.H. and Bratbak G., 2002. Flow cytometric analysis of an Emiliana huxleyi bloom terminated by viral infection. Aqua. Microb. Ecol., 27, 111-124.

Jacquet S., Domaizon I., Personnic S., Duhamel S., Heldal M., Pradeep Ram A.S. and Sime-Ngando T., 2005. Estimates of protozoan and virus-mediated mortality of bacterioplankton in Lake Bourget (France). Freshw. Biol., 50, 627-645.

Jacquet S., Miki T., Noble R., Peduzzi P. and Wilhelm S., 2010. Viruses in aquatic ecosystems: important advancements of the last 20 years and prospects for the future in microbial oceanography and limnology. Adv. Oceanogr. Limnol., 1, 71101.

Jacquet S., Dorigo U. and Personnic S., 2013. A few tests prior to flow cytometry and epifluorescence analyses of freshwater bacterioand virioplankton communities, in: Flow Cytometry: Principles, Methodology and Applications, Chapter 1, Related Nova publication, Nova Publishers Inc., New York, 1-30 p.

Kelley C.A., Coffin R.B. and Cifuentes L.A., 1998. Stable isotope evidence for alternative bacterial carbon sources in the Gulf of Mexico. Limnol. Oceanogr., 43, 1962-1969.

Koroleff F., 1976. Determination of phosphorus. In: Grass-hoff, K. (ed.), Methods of Seawater Analysis. Verlag Chemie, Weinheim, New York.

Larsen A., T. Castberg R.A., Sandaa C.P.D., Brussaard J., Egge M., Heldal A., Paulino R., Thyrhaug E., VanHannen J. and Bratbak G., 2001. Population dynamics and diversity of phytoplankton, bacteria and viruses in a seawater enclosure. Mar. Ecol. Prog. Ser., 221, 47-57.

Lebaron P., Servais P., Baudoux A.C., Bourrain M., Courties C. and Parthuisot N., 2002. Variations of bacterial-specific activity with cell size and nucleic acid content assessed by flow cytometry. Aqua. Microb. Ecol., 28, 131-140.

Li W.K.W. and Dickie P.M., 2001. Monitoring phytoplankton, bacterioplankton, and virioplankton in a coastal Inlet (Belford bassin) by flow cytometry. Cytometry 44, 236-246.

Li W.K.W., Subba-Rao D.V., Harrison W.G., Smith J.C., Cullen J.J., Irwin B. and Platt T., 1983. Autotrophic picoplankton in the tropical ocean. Science, 219, 292-29.

Liu H.B., Dagg M., Campbell L. and Urban-Rich J., 2004. Picophytoplankton and bacterioplankton in the Mississippi River Plume and its adjacent waters. Estuaries, 27, 147-156.

Marie D., Brussaard C.P.D., Thyrhaug R., Bratbak G. and Vaulot D., 1999. Enumeration of marine viruses in culture and natural samples by flow cytometry. Appl. Environ. Microb. 65, 45-52.

Marie D., Partensky F., Simon N., Guillou L. and Vaulot D., 2000. Flow cytometry analysis of marine picoplankton. In: DeMaggio S. (ed.), Living Colors: Protocols in Flow Cytometry and Cell Sorting, Springer, Berlin, 421-454.

Mathias C.B., Kirchner A.K.T. and Velimirov B., 1995. Seasonal variations of virus abundance and viral control the bacterial production in a backwater system of the Danube River. Appl. Environ. Microb., 61, 3734-3740.

Mouelhi S., Defaye D. and Balvay G., 2000. Présence de Mesocyclops ogunnus Onabamiro, 1957 (Crustacea: Copepoda) en Tunisie. Ann. Limnol. - Int. J. Lim., 36, 95-99.
Nagata T., Takai K. and Kawanobe K., 1994. Autotrophic picoplankton in southern Lake Baikal abundance, growth and grazing mortality during summer. J. Plank. Res., 16, 945-959.

Padisák J., Krienitz L., Scheffler W., Koschel R., Kristiansen J. and Grigorszky I.,1998. Phytoplankton succession in the oligotrophic Lake Stechlin (Germany) in 1994 and 1995. Hydrobiologia, 369/370, 179-197.

Padisák J., Barbosa F.A.R., Koschel R. and Krienitz L., 2003. Deep layer cyanoprokaryota maxima are constitutional features of lakes: examples from temperate and tropical regions. Arch. Hydrobiol. Spec. Issues. Adv. Limnol., 58, 175-199.

Pan L.A., Zhang L.H., Zhang J., Gasol J.M. and Chao M., 2005. On-board flow cytometric observation of picoplankton community structure in the East China Sea during the fall of different years. FEMS Microbiol. Ecol., 52, 243-253.

Parvathi A., Zhong X., Pradeep Ram A.S. and Jacquet S., 2014. Dynamics of auto- and heterotrophic picoplankton and associated viruses in Lake Geneva. Hydrol. Earth Syst. Sci., 18, 1073-1087.

Payet J.P. and Suttle C.A., 2008. Physical and biological correlates of virus dynamics in the southern Beaufort Sea and Amundsen Gulf. J. Mar. Syst., 74, 933-945.

Personnic S., Domaizon I., Dorigo U., Berdjeb L. and Jacquet S., 2009. Seasonal and spatial variability of virio-, bacterio-, and picophytoplanktonic abundances in three peri-alpine lakes. Hydrobiologia, 627, 99-116.

Pradeep Ram, A.S., Arnous, B., Danger, M., Carrias, J.F., Lacroix, G. and Sime-Ngando, T., 2010. High and differential viral infection rates within bacterial 'morphopopulations' in a shallow sand pit lake (Lac de Creteil, France). FEMS Microbiol. Ecol., 74, 83-92.

Rachiq S., Raoui M., Chadli N., Amblard C., Alaoui M.M., Carria J.F., Sime-Ngando T. and Sargos D., 2002. Potentialités phagotrophes des phytoflagellés dans la retenue de barrage Allal El Fassi (Maroc). Rev. Sci. Eau, $15,87-99$.

Ryding S.O. and Rast W., 1994. Le contrôle de l'eutrophisation des lacs et des réservoirs. Collection Sciences de l'environnement. Masson UNESCO Paris, 261 p.

Sarmiento, J.L. and Gruber, N., 2006. Ocean Biogeochemical Dynamics, Princeton University Press, Princeton, New Jersey, USA.

Schallenberg, M. and Burns C.W., 2001. Tests of autotrophic picoplankton as early indicators of nutrient enrichment in an ultra-oligotrophic lake. Freshw. Biol., 46, 27-37.

Sellami I., Ayadi H., Bouain A., Aleya L. and Mhamdi M.H., 2009. Distribution of zooplankton related to environmental factors in three interconnected reservoirs: Kasseb, Mornaguia and Ghdir El Goulla (North of Tunisia). Ann. Limnol. - Int. J. Lim. 45, 107-117.

Sellami I., Ben Romdhane S., Guermazi W., El Bour M., Hamza A., Mhamdi M.H., Pinel-Alloul B., Aleya L. and Ayadi H., 2012. Seasonal dynamics of plankton communities coupled with environmental factors in a semi arid area: Sidi Saâd reservoir (Center of Tunisia). Afric. J. Biotechnol., 11, 865-877.

Shiah F.K. and Ducklow H.W., 1994. Temperature regulation of heterotrophic bacterioplankton biomass, production and specific growth rate in the Chesapeake Bay. Limnol. Oceanogr., 39, 1243-1258. 
Short S.M. and Suttle C.A., 2003. Temporal dynamics of natural communities of marine algal viruses and eukaryotes. Aquat. Microb. Ecol., 32, 107-119.

Simek K., Pernthaller J., Weinbauer M.G., Hornak K., Dolan J.R., Nedoma J., Masin M. and Amann R., 2001. Changes in bacterial community composition and dynamics and viral mortality rates associated with enhanced flagellate grazing in a mesoeutrophic reservoir. Appl. Environ. Microb., 67, $2723-2733$.

Stockner J.G. and Antia N.J., 1986. Algal picoplankton from marine and freshwater: a multidisciplinary perspective. Can. J. Fish. Aquat. Sci., 43, 2472-2503.

Stockner J.G. and Shortreed K.S., 1994. Autotrophic picoplankton community dynamics in a pre-alpine lake in British Columbia, Canada. Hydrobiologia, 274, 133-142.

Stockner J.G., Callieri C. and Cronberg G., 2000. Picoplankton and other non-bloom forming cyanobacteria in lakes. In: Whitton B. and Potts M. (eds.), Ecology of Cyanobacteria: Their Diversity in Time and Space, Kluwer Academic Publishers, Dordrect, 195-231 p.

Suttle, C.A., 2005. Viruses in the sea. Nature, 437, 356-361.

Szelag-Wasielewska E., 1999. Picoplankton and other size groups of phytoplankton in various shallow lakes. Hydrobiologia, 342/343, 79-85.

Tijdens M., Hans L., Hoogveld Miranda P., Kamst-van A., Stefan G.H., Simis Baudoux A., Hendrikus C., Laanbroek J. and Herman J.G., 2008. Population dynamics and diversity of viruses, bacteria and phytoplankton in a shallow eutrophic lake. Microb. Ecol., 56, 29-42.

Tsai A.Y., Gong G.C., Chiang K.P., Chao C.F., Liao H.K. and Shiah F.K., 2011. Temporal and spatial variations of picoplankton and nanoplankton and short-term variability related to stormy weather in the Danshui River estuary in northern Taiwan. Terrest. Atmos. Ocea. Sci., 22, 79-89.

Turki S., 2002. Contribution à l'étude bio-écologique des rotifères, cladocères, copépodes des eaux continentales Tunisiennes et dynamique saisonnière du zooplancton de la retenue du barrage Bir M'Chergua. Thèse doct. instit. Nat. Sci. Tech. de la mer. 203 p.

Vaque D., Casamayor E.O. and Gasol J.M., 2001. Dynamics of whole community bacterial production and grazing losses in seawater incubations as related to the changes in the proportions of bacteria with different DNA content. Aquat. Microb. Ecol., 25, 163-177.

Vaulot D., 1989. CYTOPC: processing software for flow cytometric data. Signal Noise, 2, 8.

Vila X. and Abella C.A., 2001. Light- harvesting adaptations of planktonic phototrophic micro-organisms to different light quality conditions. Hydrobiologia, 452, 15-30.

Voros L., Callieri C., Balogh K.V. and Bertoni R., 1998. Freshwater picocyanobacteria along a trophic gradient and light quality range. Hydrobiologia, 369/370, 117-125.

Vrede K., Vrede T., Isaksson A. and Karlsson A., 1999. Effects of nutrients (phosphorous, nitogen and carbon) and zooplankton on bacterioplankton and phytoplankton - a seasonal study. Limnol. Oceanogr., 44, 1616-1624.

Waite A.M., Safi K.A., Hall J.A. and Nodder S.D., 2000. Mass sedimentation of picoplankton embedded in organic aggregates. Limnol. Oceanogr., 45, 87-97.

Wakabayashi T. and Ichise S., 2004. Seasonal variation ofphototrophic picoplankton in Lake Biwa (1994-1998). Hydrobiologia, 528, 1-16.
Wang B., Liu F., Wang C.Q., Yu, Y. and Wu, Y., 2009. Flow cytometric observation of picophytoplankton community structure in the cascade reservoirs along the Wujiang River, SW China. J. Limnol., 68, 53-63.

Wehr J.D., 1993. Effects of experimental manipulation of light and phosphorus supply on competition among picoplankton and nanoplankton in oligotrophic lake. Can. J. Fish. Aquat. Sci. 50, 936-945.

Weinbauer M.G., 2004. Ecology of prokaryotic viruses. FEMS Microbiol. Rev., 28, 127-181.

Weinbauer M.G. and Hofle M.G., 1998. Significance of viral lysis and flagellate grazing as factors controlling bacterioplankton production in a eutrophic lake. Appl. Environ. Microb., 64, 431-438.

Weinbauer M.G. and Peduzzi P., 1995. Effect of virus-rich high molecular weight concentrates of seawater on the dynamics of dissolved amino acids and carbohydrates. Mar. Ecol. Prog. Ser., 127, 245-253.

Weinbauer M.G. and Rassoulzadegan, F., 2004. Are viruses driving microbial diversification and diversity. Environ. Microb., 6, 1-11.

Weisse, T., 1993. Dynamics of autotrophic picoplankton in marine and freshwater ecosystems. In: Jones J.G. (ed.), Advances in Microbial Ecology, Plenum, New York, 327370 .

Weisse T. and Schweizer, A., 1991. Seasonal and interannual variation of autotrophic picoplankton in a large prealpine lake (Lake Constance). Verhand lungender Internationale Vereinigung fur Theoretische undangewandte Limnologie, 24, 821-825.

Welschmeyer NA., 1994. Fluorimetric analysis of chlorophyll $a$ in the presence of chlorophyll $b$ and pheopigments. Limnol. Ocean., 39, 1985-1992.

Whitman W.B., Coleman, D.C. and Wiebe, W.J., 1998. Prokaryotes: the unseen majority. Proc. Natl. Acad. Sci. USA, 95, 6578-6583.

Wilson W.H. and Mann, N.H., 1997. Lysogenic and lytic viral production in marine microbial communities. Aquat. Microb. Ecol., 13, 95-100.

Wommack K.E. and Colwell R.R., 2000. Virioplankton: viruses in aquatic ecosystems. Microb. Mol. Biol. Rev., 64, 69-114.

Wommack K., Hill, R.T., Kessel, M., Russek-Cohen, E. and Colwell, R.R., 1992. Distribution of viruses in the Chesapeake Bay. Appl. Environ. Microb., 58, 2965-2970.

Wommack K., Ravel, J., Hill, R.T., Chun J.S. and Colwell R.R., 1999. Population dynamics of Chesapeake bay virioplankton: total community analysis by pulsed-field gel electrophoresis. Appl. Environ. Microbiol., 65, 231-240.

Worden A.Z. and Not, F., 2008. Ecology and diversity of picoeukaryotes In: Kirchman D. (ed.), Book Chapter in: Microbial Ecology of the Ocean (2nd edn), Wiley, San Francisco.

Yuan X.C., He, L., Yin, K.D., Pan, G. and Harrison, P.G., 2011. Bacterial distribution and nutrient limitation in relation to different water masses in the coastal and northwestern South China Sea in late summer. Continent. Shelf Res., 31, 12141223.

Zhang X., Zhen, S., Qingxia, L., Feng, Y., Lei T. and Xiaoping H., 2013. Spatial and temporal variations of picoplankton in three contrasting periods in the Pearl River Estuary, South China. Continent. Shelf Res., 15, 1016-2013. 